\title{
Analysis of the relationship between premature rupture of membranes with delivery method and newborn asphyxia
}

\author{
Azizah Nurdin ${ }^{1 *}$, Haizah Nurdin², Rahmayanti ${ }^{3}$, Mutmainnah Sari $^{4}$

\begin{abstract}
${ }^{1}$ Department of Obstetrics and Gynecology, Faculty of Medicine and Health Sciences, UIN Alauddin Makassar, Makassar, Indonesia

${ }^{2}$ Department of Anaesthesiology, Faculty of Medicine, Hasanuddin University, Makassar, Indonesia

${ }^{3}$ Medical Degree, Faculty of Medicine and Health Sciences, UIN Alauddin Makassar, Makassar, Indonesia

${ }^{4}$ Department of Nursing, Faculty of Medicine and Health Sciences, UIN Alauddin Makassar, Makassar, Indonesia
\end{abstract}

Received: 12 October 2021

Accepted: 09 November 2021

\author{
*Correspondence: \\ Azizah Nurdin, \\ E-mail: azizah.nurdin@uin-alauddin.ac.id
}

Copyright: $($ ) the author(s), publisher and licensee Medip Academy. This is an open-access article distributed under the terms of the Creative Commons Attribution Non-Commercial License, which permits unrestricted non-commercial use, distribution, and reproduction in any medium, provided the original work is properly cited.

\begin{abstract}
Background: As many as $20 \%$ of maternal deaths are caused by premature rupture of membranes (PROM). The high rate of PROM is believed to affect newborn asphyxia. In addition, the high rate of cesarean section is one of the reasons or most frequent indications of PROM. Therefore, researchers were interested in knowing how the relationship between PROM and delivery method and newborn asphyxia was.

Methods: This study was an analytical study conducted with a cross-sectional approach by taking secondary data from patients through medical records of pregnant women who experienced PROM in January 2020 to July 2021.

Results: This study found that the incidence of PROM was more dominant in multiparous women 55.4\%, in term pregnancy $79.2 \%$, duration of $P R O M \geq 12$ hours $55.4 \%$, have normal leukocyte levels $76.2 \%$, the incidence of asphyxia (mild asphyxia) $90.1 \%$ and the rate of cesarean section as much as $24 \%$. The bivariate analysis found a significant relationship between the length of PROM and the method of delivery ( $\mathrm{p}$ value 0.049 ) and the duration of PROM with newborn asphyxia ( $\mathrm{p}$ value 0.040 ) and there was no significant relationship between maternal leukocyte count and newborn asphyxia (p value 0.444 ).

Conclusions: The longer the duration of PROM with delivery, the greater the chance of infection for the mother and fetus. The length or duration of PROM will have an impact on the method of delivery and increase the likelihood of asphyxia in newborns.
\end{abstract}

Keywords: Premature rupture of membranes, Labor, Asphyxia, Leukocytes, Caesarean section

\section{INTRODUCTION}

The maternal mortality rate (MMR) is the proportion of maternal deaths caused by pregnancy, childbirth or postpartum care but not by other causes such as accidents or falls. ${ }^{1}$ Maternal death according to the WHO is maternal death during pregnancy or 42 days after delivery due to causes or aggravated by pregnancy and not due to trauma or injury and it is estimated that in 2017 around 810 women died every day due to complications and childbirth. $^{2}$
Some of the common causes of maternal deaths include bleeding $28 \%$, infection of PROM $20 \%$, eclampsia $12 \%$, abortion $13 \%$, prolonged labor $18 \%$ and other causes $2 \%{ }^{1}$ One of the infections that most often causes death is endometritis and postpartum subinvolution due to premature rupture of membranes during intrapartum. The incidence of PROM is considered quite high when compared to other pregnancy problems. The percentage of PROM both at term and preterm is about $10 \%$ of all pregnancies and is more common in primigravida, while PROM at term has an incidence of about $8 \%$ of all term in 
the world. ${ }^{3}$ Spontaneous labor after premature rupture of membranes usually occured within 24 hours, with $79 \%$ of women delivering spontaneously within 12 hours and $95 \%$ within 24 hours. $^{4}$

The majority of patients with PROM experienced a 24 hour latent phase as much as $26.7 \%$, while the highest perinatal morbidity cases were caused by PROM for 12-24 hours as much as $30 \%$ and mortality among perinatal cases was $5 \%$ within $12-24$ hours and $>24$ hours. In preterm PROM, infant survival rates at discharge were only $14.1 \%$, $39.5 \%, 66.8 \%$ and $75.8 \%$ at $22,23,24$ and 25 weeks respectively. ${ }^{5}$

The high incidence of intrapartum infection caused by PROM allows increased maternal mortality. ${ }^{7}$ In addition, the delivery method taken at the time of infection must really pay attention to aspects of the safety of the baby and mother. Although caesarean section is not a completely safe procedure, considering aspects of the safety of the mother and baby as well as the advantages and disadvantages of the procedure, the procedure for choosing a method of delivery can be considered in order to improve maternal and infant outcomes.
The high rate of premature rupture of membranes is believed to affect newborn asphyxia. ${ }^{8}$ Babies with a lower Apgar score are believed to be one of the outcomes of childbirth that experience infection, one of which is PROM. In addition, the high rate of cesarean section is one of the reasons or the most frequent indication of premature rupture of membranes. ${ }^{9}$

However, not all premature rupture of membranes must end with abdominal delivery, considering the condition of the mother and baby. Therefore, researchers are interested in knowing how the relationship between premature rupture of membranes and the method of delivery was and newborn asphyxia.

\section{METHODS}

\section{The research plan}

This study was an analytical study conducted with a crosssectional approach by taking secondary data from patients through the medical records of pregnant women who experienced PROM in January 2020 to July 2021.

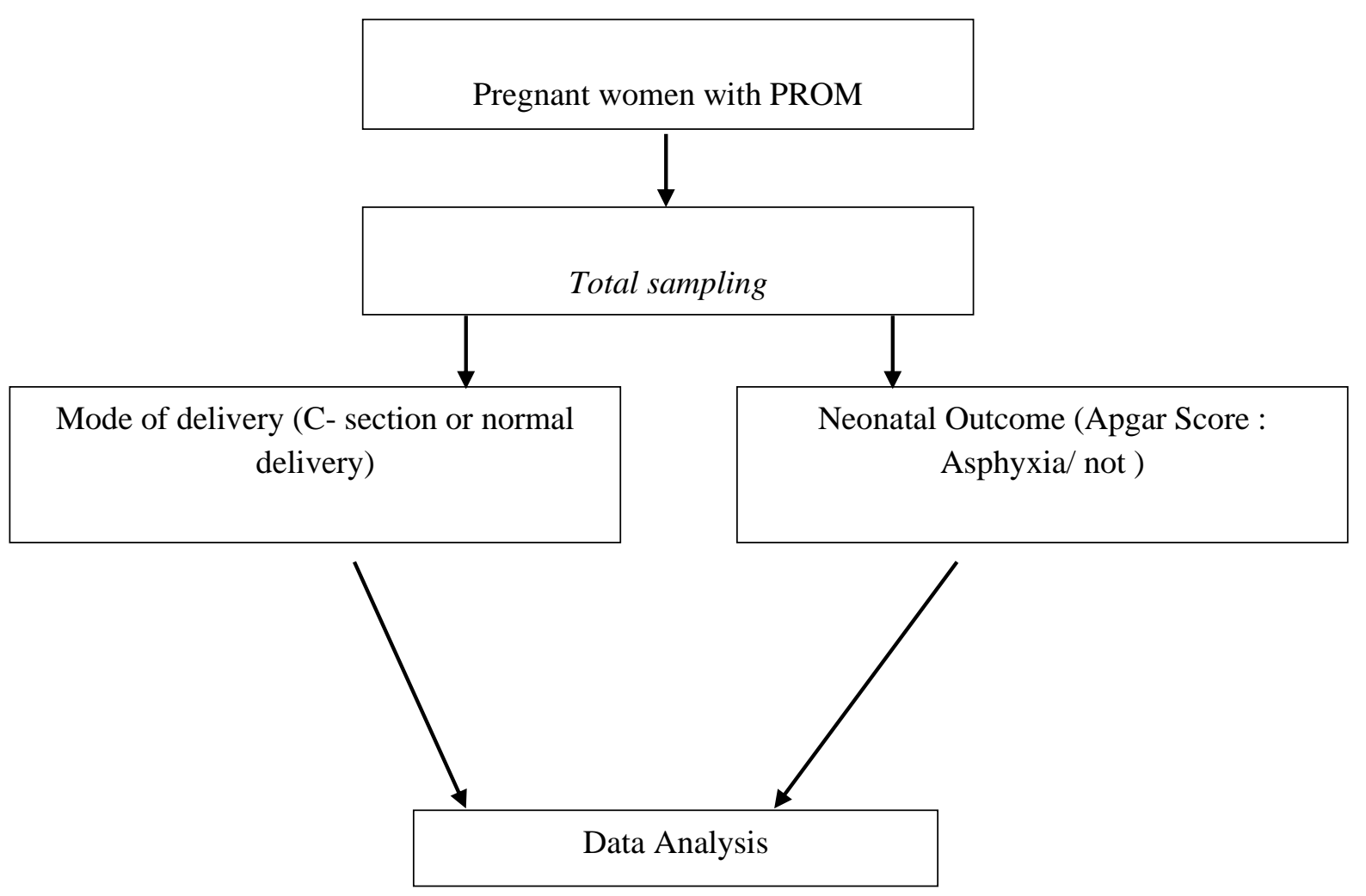

Figure 1: Research flow.

\section{Samples and the population}

The data on pregnant women with PROM used in this study came from secondary data in the PKU Muhammadiyah Mamajang hospital's medical records. The data was taken by total sampling starting of complete medical records from January 2020 to July 2021.

\section{Variable or instrument}

The variables assessed in this study were pregnant women who experienced PROM as evidenced by history taking and confirmed by examination of the patient's nitrazine test at the time of vaginal examination upon admission to the 
hospital at the maternal ER at PKU Muhammdiyah hospital Mamajang. The nitrazine test was a conventional test for testing the $\mathrm{pH}$ of the amniotic fluid to assess the presence of PROM and had been used since 1938. ${ }^{10}$

Other variables were the method of delivery of the baby and the Apgar score, which was calculated at the time of birth and recorded in the medical record status. Newborns with an Apgar score $<7$ in the first and fifth minutes after delivery were defined as having birth asphyxia, while newborns with an APGAR score of 7 in the first and fifth minutes were considered not to have birth asphyxia (Chart 1). ${ }^{11}$

\section{Data analysis}

Data analysis in this study used the Chi square test to see the relationship between PROM with delivery method and newborn asphyxia.

\section{Ethical approval}

Researchers made administrative preparations before researching, namely submitting a letter of ethics and a statement of passing the ethical test. A statement letter on research ethics was issued by the health research ethics commission of the faculty of medicine and health sciences of UIN Alauddin Makassar with a recommendation of ethical approval number B.145/KEPK/FKIK/IX/2021.

\section{RESULTS}

\section{Characteristics of pregnant women}

In this study, a sample of 101 pregnant women who gave birth with a diagnosis of PROM were found. From a total of 101 data on pregnant women, the majority were aged 20-35 years with a percentage of $68.3 \%$ and the dominant parity status of multigravida was 56 people $(55.4 \%)$.

The majority of gestational age at term were 80 people (79.2\%), the dominant education level was in the high category as many as 81 people $(80.2 \%)$, the majority of PROM duration was $\geq 12$ hours as many as 56 people $(55.4 \%)$ and the majority of leukocytes were normal $\left(5,000-14,000 \mathrm{~mm}^{3}\right), 77$ people $(76.2 \%)$. The majority of term $\mathrm{PROM} \geq 12$ hours were 44 people $(55.0 \%)$, the majority of preterm PROM $\geq 12$ hours were 12 people (57.1\%), 80 people (79.2\%) had dominant PROM status at term, mild asphyxia status (Apgar score 7-10) as many as 91 people $(90.1 \%)$ and the majority method of delivery was normal, as many as 77 people $(76.2 \%)$ (Table 1$)$.

Table 1: Characteristics of pregnant women who underwent labor with a diagnosis of PROM.

\begin{tabular}{|c|c|c|}
\hline \multirow{2}{*}{ Characteristics } & \multicolumn{2}{|c|}{ Jumlah } \\
\hline & Total & $\%$ \\
\hline \multicolumn{3}{|l|}{ Age (in years) } \\
\hline$<20$ & 13 & 12.9 \\
\hline $20-35$ & 69 & 68.3 \\
\hline$>35$ & 19 & 18.8 \\
\hline \multicolumn{3}{|l|}{ Parity } \\
\hline Primigravida & 45 & 44.6 \\
\hline Multigravida & 56 & 55.4 \\
\hline \multicolumn{3}{|l|}{ Gestational age } \\
\hline Preterm & 21 & 20.8 \\
\hline Term & 80 & 79.2 \\
\hline \multicolumn{3}{|l|}{ Education } \\
\hline Low & 20 & 19.8 \\
\hline High & 81 & 80.2 \\
\hline \multicolumn{3}{|l|}{ Working status } \\
\hline Working & 24 & 23.8 \\
\hline Not working & 77 & 76.2 \\
\hline \multicolumn{3}{|c|}{ PROM duration (in hours) } \\
\hline$<12$ & 45 & 44.6 \\
\hline$\geq 12$ & 56 & 55.4 \\
\hline \multicolumn{3}{|l|}{ Leukocytes } \\
\hline Normal & 77 & 76.2 \\
\hline Leukocytosis & 24 & 23.8 \\
\hline \multicolumn{3}{|c|}{ PROM in term (in hours) } \\
\hline$<12$ & 36 & 45.0 \\
\hline$\geq 12$ & 44 & 55.0 \\
\hline PROM in preter & & \\
\hline
\end{tabular}




\begin{tabular}{|lll|}
\hline Characteristics & Jumlah & \% \\
\hline$<12$ & Total & 42.9 \\
\hline$\geq 12$ & 9 & 57.1 \\
\hline PROM & 12 & \\
\hline Term & & 79.2 \\
\hline Preterm & 80 & 20.8 \\
\hline Asphyxia & 21 & \\
\hline Mild & & 90.1 \\
\hline Moderate & 91 & 9.9 \\
\hline Delivery method & 10 & \\
\hline Normal & & 76.2 \\
\hline C-Section & 77 & 23.8 \\
\hline Total & 24 & 100.0 \\
\hline
\end{tabular}

Table 2: The relationship between the length of the PROM and the method of delivery for pregnant women.

\begin{tabular}{|c|c|c|c|c|c|}
\hline \multirow{2}{*}{\multicolumn{2}{|c|}{ PROM duration }} & \multicolumn{2}{|c|}{ Mode of delivery } & \multirow{2}{*}{ Total } & \multirow{2}{*}{ P value } \\
\hline & & Normal & C section & & \\
\hline \multirow{2}{*}{$<12$} & $\mathrm{~N}$ & 39 & 6 & 45 & \multirow{6}{*}{0.049} \\
\hline & $\%$ & 86.7 & 13.3 & 100.0 & \\
\hline \multirow{2}{*}{$\geq 12$} & $\mathrm{~N}$ & 38 & 18 & 56 & \\
\hline & $\%$ & 67.9 & 32.1 & 100.0 & \\
\hline \multirow{2}{*}{ Total } & $\mathrm{N}$ & 77 & 24 & 101 & \\
\hline & $\%$ & 76.2 & 23.8 & 100.0 & \\
\hline
\end{tabular}

Table 3: The relationship between PROM and newborn asphyxia.

\begin{tabular}{|lllll|}
\hline \multirow{2}{*}{ PROM duration } & \multicolumn{5}{c|}{ New born outcome } & Total & P value \\
\hline \multirow{2}{*}{$\mathbf{1 2}$} & $\mathrm{N}$ & 44 & 1 & 45 \\
\cline { 2 - 5 } & $\%$ & 97.8 & 2.2 & 100.0 \\
\multirow{2}{*}{$\mathbf{1 2}$} & $\mathrm{N}$ & 47 & 9 & 56 \\
\hline \multirow{2}{*}{ Total } & $\%$ & 83.9 & 16.1 & 100.0 \\
\cline { 2 - 5 } & $\mathrm{N}$ & 91 & 10 & 101 \\
\hline
\end{tabular}

Table 4: Relationship of maternal leukocytes with asphyxia of newborns.

\begin{tabular}{|c|c|c|c|c|c|}
\hline \multirow{2}{*}{\multicolumn{2}{|c|}{ Leucocytes }} & \multicolumn{2}{|c|}{ New born outcome } & \multirow{3}{*}{$\begin{array}{l}\text { Total } \\
77\end{array}$} & \multirow{2}{*}{$P$ value } \\
\hline & & No asphyxia & No asphyxia & & \\
\hline \multirow{2}{*}{ Normal } & $\mathrm{N}$ & 68 & 9 & & \multirow{6}{*}{0.444} \\
\hline & $\%$ & 88.3 & 11.7 & 100.0 & \\
\hline \multirow{2}{*}{ Leukocytosis } & $\mathrm{N}$ & 23 & 1 & 24 & \\
\hline & $\%$ & 95.8 & 4.2 & 100.0 & \\
\hline \multirow{2}{*}{ Total } & $\mathrm{N}$ & 91 & 10 & 101 & \\
\hline & $\%$ & 90.1 & 9.9 & 100.0 & \\
\hline
\end{tabular}

The long-term relationship of PROM with the method of delivery

In this study, it was shown that there was a significant relationship between the duration of PROM and the method of delivery in pregnant women with a $\mathrm{p}$ value of $0.049<0.05$ (Table 2).

\section{The long-term relationship of PROM with newborn asphyxia}

In this study, it was shown that there was a significant relationship between duration of PROM and asphyxia of newborns with a p value of $0.040<0.05$ (Table 3). 


\section{The relationship of maternal leukocytes with newborn asphyxia}

In this study, it was shown that there was no significant relationship between maternal leukocyte count and newborn asphyxia with a p value of $0.444>0.05$ (Table 4 ).

\section{DISCUSSION}

In this study, it was found that the incidence of PROM was more dominant in multiparous women with 56 patients $(55.4 \%)$. This study was in accordance with research conducted by Habte et al 2021 and Ramseyer et al 2020 which showed that the incidence of PROM was more dominant in multiparas. ${ }^{12,13}$ This was different from the research conducted by Ibishi et al 2015 and Chandra et al 2020 which found that the incidence of PROM tended to be suffered by primiparous women. ${ }^{14,15}$

In this study, PROM dominantly occurred in term pregnancy with a total of 80 patients $(79.2 \%)$ compared to preterm PROM as many as 21 patients $(20.8 \%)$. This study was in line with research conducted by Begum et al 2018 in Dhaka which found that PROM dominantly occurred in term pregnancies as much as $55 \%$ and preterm pregnancies in $45 \% .{ }^{16}$ A similar study was also presented by Habte et al 2021 which stated that PROM was dominant in term pregnancies with a percentage of $60.9 \% .{ }^{12}$ In addition, in this study, the majority of PROM durations were $\geq 12$ hours in as many as 56 patients $(55.4 \%)$. This was different from Chandra et al 2020, which stated that the majority of PROM durations were $<12$ hours with a percentage of $76.5 \%$ and $\geq 12$ hours with a percentage of $23.50 \% .{ }^{15}$ This study also found that the majority of patients with PROM had normal leukocyte levels, as many as 77 people (76.2\%). This was in line with the study of Pramono et al 2020 , which stated that $60 \%$ of patients with PROM did not experience leukocytosis. ${ }^{17}$ Maternal leukocyte counts cannot identify the presence of microbial invasion into the amniotic cavity or intra-amnionic inflammation in women with PROM before delivery. ${ }^{18}$ In addition, this study also found the incidence of asphyxia in mothers with PROM, namely mild asphyxia in as many as 91 babies (90.1\%). This was in line with the research of Babih et al 2020, which stated that as many as $44 \%$ of PROM cases cause asphyxia in infants. ${ }^{19}$ Another supporting study, namely Chandra et al 2020, stated that as many as $55.4 \%$ of PROMs caused infant asphyxia. ${ }^{15}$

In this study, the percentage of caesarean section rates in the incidence of PROM was 24\%. Several other studies from various references also found the incidence of cesarean section in PROM cases to be up to $28 \%, 30 \%$ and $26 \% .{ }^{14,15,20}$ Bivariate analysis in this study, related to the duration of PROM with the method of delivery, showed a significant relationship with a p value of 0.049 . Although there was no statistically significant difference in neonatal/perinatal mortality, according to a study by Kayiga et al (2018) in terms of different modes of delivery, in low-resource settings, vaginal delivery was a safer mode of delivery. Vaginal birth causes less maternal and perinatal morbidity than cesarean section. These data supported the practice that has been adopted in highincome countries regarding planned vaginal delivery for PROM and should be adopted as standard practice in lowand middle-income countries. ${ }^{21}$ The longer the duration of PROM with delivery, the greater the possibility of infection for the mother and fetus.

In this study, it was also found that there was a significant relationship between the duration of premature rupture of membranes and asphyxia in newborns with a $\mathrm{p}$ value of 0.040 , namely in premature rupture of membranes more than 12 hours, $16.1 \%$ more infants suffered from moderate asphyxia compared to PROM. Sample with experience PROM $<12$ hours suffering from moderate asphyxia only $2.2 \%$ of the total sample. In line with this study, a study in Batam with 91 samples also found that there was a relationship between the incidence of premature rupture of membranes and neonatal asphyxia. ${ }^{22}$ However, Begum's research 2018 in Dhaka also showed an increase in infant mortality by $7 \%$ due to premature rupture of membranes, where one of the causes of infant mortality was severe asphyxia, respiratory distress and sepsis. ${ }^{16}$ However, a study conducted by Al Fattah with 175 samples found that the duration of premature rupture of membranes was not associated with the presence of asphyxia of the newborn but related with gestational age and the number of leukocytes. The sample found that the duration of premature rupture of membranes was not associated with the presence of asphyxia of the newborn but related with gestational age and the number of leukocytes. ${ }^{23}$ This study showed that there was no significant difference between the leukocyte count of mothers with PROM and asphyxia in infants with a $p$ value of 0.444 . This study was in line with Pramono et al 2020, which stated that there was no significant difference between the number of maternal leukocytes and the incidence of PROM, with a percentage of $62.5 \%$ of infants not having asphyxia. ${ }^{17}$ Maternal leukocyte levels at the time of hospital admission cannot be used as a standard-criteria as a non-invasive screening tool to identify complications in mothers with PROM. ${ }^{18}$

\section{Limitations}

Our research has several limitations, one of which was due to the retrospective method which allowed data not to be obtained at the same time, but we tried to minimize this by taking complete data in medical records and using the most recent data started from January 2020 to July 2021.

\section{CONCLUSION}

This study confirmed that there was a significant relationship between the length of PROM and the method of delivery and also the duration of PROM with newborn asphyxia. The longer the duration of PROM with delivery, the greater the chance of infection for the mother and fetus. The length or duration of PROM will have an impact on 
the method of delivery and increase the likelihood of asphyxia in newborns.

Funding: Medical Study Program, Faculty of Medicine and Health Sciences UIN Alauddin Medical Doctor Program

Conflict of interest: None declared

Ethical approval: The study was approved by the Institutional Ethics Committee

\section{REFERENCES}

1. Ministry of Health Republic of Indonesia. Fact sheet: Indonesia's Health Profile in 2018. Available at: https://pusdatin.kemkes.go.id/resources/download/pu sdatin/profil-kesehatanindonesia/PROFIL_KESEHATAN_2018_1.pdf. Accessed on 30 September 2021.

2. WHO. Fact sheet: Sexual and reproductive health, 2019. Available at: https://www.who.int/reproductivehealth/topics/en/. Accessed on 30 September 2021.

3. Surayapalem S, Cooly V, Salicheemala B. A study of maternal and perinatal outcome in premature rupture of membranes at term. Int J Clin Obstet Gynaecol. 2019;3(2).

4. Wagner A, Pimentel VM, Ejckardt MJ. Maternal Health. In: Gupta N, Kasper H, eds. The mass general hospital for children handbook of pediatric global health. New York: Springer; 2017: 73-86.

5. Mahajan C, Faruqi M. Maternal and perinatal outcome in pregnancy complicated by premature rupture of membranes (Prom): a prospective study. Int J Clin Obstet Gynaecol. 2020;4(2):19-23.

6. Dayal S, Hong PL. Premature rupture of membranes. United States of America: StatPearls Publishing; 2021.

7. Gupta S, Malik S, Gupta S. Neonatal complications in women with premature rupture of membranes (PROM) at term and near term and its correlation with time elapsed since PROM to delivery. Trop Doct. 2020;50(1):8-11.

8. Kalem MN, Köşüş A, Kamalak Z, Köşüş N, Kalem Z. Factors affecting the rates of caesarean sections in cases with premature rupture of membranes (PROM) at term. J Inst Obstet Gynaecol. 2017;37(5):585-90.

9. Eskicioglu F, Gur EB. Diagnostic modalities in premature rupture of membranes. Int J Women's Heal Reprod Sci. 2015;3(2):89-92.

10. Kune G, Oljira H, Wakgari N, Zerihun E, Aboma M. Determinants of birth asphyxia among newborns delivered in public hospitals of West Shoa Zone, Central Ethiopia: a case-control study. PLoS One. 2021;16(3).
11. Habte A, Dessu S, Lukas K. Determinants of premature rupture of membranes among pregnant women admitted to public hospitals in Southern Ethiopia, 2020: a hospital-based case-control study. Int J Womens Health. 2021;13:613-26.

12. Ramseyer AM, Whittington JR, Magann EF, Pates JA, Ounpraseuth ST. Can maternal characteristics on admission for preterm prelabor rupture of membranes predict pregnancy latency? Am J Obstet Gynecol MFM. 2020;2(4).

13. Ibishi VA, Isjanovska RD. Prelabour rupture of membranes: mode of delivery and outcome. Open Access Maced J Med Sci. 2015;3(2):237-40.

14. Chandra SN, Pradeep M, Shashikumara. Maternal and neonatal outcomes and the associated risk factors for premature rupture of membranes. J South Asian Fed Obstet Gynaecol. 2020;12(6):402-7.

15. Begum H, Roy M, Shapla NR. Perinatal outcome of premature rupture membrane in pregnancy. J Dhaka Med Coll. 2017;26(2):135-9.

16. Pramono BA, Wiyati PS, Dewantiningrum J. Differences of maternal leukocyte count in premature rupture of membranes and preterm premature rupture of membranes. Bali Med J. 2020;9(3):868-71.

17. Musilova I, Pliskova L, Gerychova R, Janku P, Simetka O, Matlak P, et al. Maternal white blood cell count cannot identify the presence of microbial invasion of the amniotic cavity or intra-amniotic inflammation in women with preterm prelabor rupture of membranes. PLoS One. 2017;12(12).

18. Bayih WA, Yitbarek GY, Aynalem YA, Abate BB, Tesfaw A, Ayalew MY, et al. Prevalence and associated factors of birth asphyxia among live births at Debre Tabor General Hospital, North Central Ethiopia. BMC Pregnancy Childbirth. 2020;20:653.

19. Agnes JMB, Lavanya S. Two-year comparative study on immediate versus delayed induction in term premature rupture of membranes. Int $\mathbf{J}$ Reprod Contracept Obstet Gynecol. 2018;7(1):94-8.

20. Kayiga H, Lester F, Amuge PM, Byamugisha J, Autry AM. Impact of mode of delivery on pregnancy outcomes in women with premature rupture of membranes after 28 weeks of gestation in a lowresource setting: a prospective cohort study. PLoS One. 2018;13(1).

21. Aldiano R, Deskawati F. Relationship of premature rupture of membranes (PROM) with neonatory asphysia in santa elisabeth hospital batam city. Zo Kedokt. 2021;11(1):42-8.

22. Fattah AN, Purwosunu Y, Sungkar A, Prameswari N. Can we predict birth asphyxia of neonates born from PPROM women? Int J Reprod Contracept Obstet Gynecol. 2017;6(10):4237-42.

Cite this article as: Nurdin $\mathrm{A}$, Nurdin $\mathrm{H}$, Rahmayanti, Sari M. Analysis of the relationship between premature rupture of membranes with delivery method and newborn asphyxia. Int J Reprod Contracept Obstet Gynecol 2021;10:4377-82. 